\title{
Algunas Obras de Sarah Bollo, Poetisa Uruguaya
}

GARAH Bollo es ante todo una escritora cerebral. Es abogada, bien $\checkmark$ conocida en las repúblicas rioplatenses por la elocuencia y el alto vutelo de sus conferencias. En la tranquila calle Colonia de la ciudad de Montevideo, lleva su plena vida esta mujer de facciones clásicas de estatua griega, de pelo negro y abundante y ojos penetrantes a la vez que bondadosos. Hablo de la plenitud de su vida, porque Sarah Bollo se ocupa de un sinfín de cosas: la abogacía por supuesto (que para nosotros es lo de menos en el análisis de su vida), los quehaceres del hogar, las relaciones familiares y amistades, y - para nosotros lo principal- la devoción a las musas.

Fué a saludar a la notable poetisa mi hija menor, dándole los saludos míos que eran del caso y manifestándole que hacía tiempo que yo tenía ganas de conocer su obra. Accediendo gentilmente a la petición que traían las frases const1etudinarias de quien entrevista a los poetas, Sarah le regaló a la visitante tres libros: Las voces ancladas; Regreso; Baladas del corazón cercano. Su producción es más extensa, pero hoy es difícil conseguir ejemplares de las primeras obras: Diálogo de las luces perdidas (1927); Los nocturnos del fuego (1931), y la de crítica, La poesia de Juana de Ibarbourou (1935). La reseña que aquí trazamos se limitará pues a las obras mencionadas.

Las voces ancladas. Son "poemas en prosa". Esta frase, ¿qué quiere decir? Si tiene valor alguno, significará que los escritos así llamados, sin someterse a las reglas de la versificación, pretenden alcanzar un grado de expresión estética únicamente permitido a los que saben crear algo. ¿ Ha sido creadora Sarah en Las voces ancladas? Sí, porque este pequeño libro trae cierta comprensión, nacida del su- 
frimiento, de la sumisión y de la resignación, que solamente la mujer es capaz de poseer. Quizá se me dirá que todo esto es cosa pasiva, y no acto de creación, a lo cual respondo que el evocar así voces de hormigas, hiedra, nubes y lagunas, ya es crear. El mundo, por lo general, no cree que tales cosas tengan vida ni puedan proporcionarnos enseñanzas provechosas y espirituales. Es decir, el vulgo les niega vida y valor espiritual. Las evocaciones de esta poetisa insisten en que sí hay vida en ellas, y para la visión de la fe hay enseñanzas saludables. Así triunfa ella sobre el materialismo actual, y así crea algo nuevo: la victoria de lo humilde y lo abnegado. Si me dice alguien que esto no se diferencia de las fábulas de Esopo y de La Fontaine, responderé que la moraleja en éstas es de la mente, no del alma; es lógica, y no es fe. Sarah Bollo cree: bienaventurados son los humildes. Citaré solamente la poesía de "El río".

(Dice el río:) "-Mis músicas vibran con las lágrimas de mi corazón. Ellas nacen del tormento de mi alma. Tú (v. gr., el tallo) suftes y olvidas, hoguera prontamente extinguida. Yo voy con el pecho herido por los fulgurantes guijarros y traspasado por los espadosos juncos. Muero un poco en cada armonía, armiño sembrado con $\mathrm{mi}$ joven sangre. Mi canto es mi suprema belleza, mi lacerante soledad, mi divino castigo. El río, poeta, así decía."

La clara comprensión de "E1 río" está igualada en otros poemas, de los cuales menciono "Renacer", "Viaje ascendente", "La nube y la laguna", y, de la segunda parte del libro, titulada "Los regresos", "Regreso" y "Puertos". Admirable es el tema de "Regreso", si bien es verdad que no respira mucha resignación: trata del caso de un joven que quiere marcharse a otro país, pero siendo muy pobre tiene que esconderse en la escotilla de un barco. En el instante de partir, es descubierto y le hacen volver a la tierra que pensaba dejar para siempre.

... Y todavía los hombres no han sabido exigir el libre paso en el vasto camino de todos, la dulce mar...

He hablado de la fuerza creadora de la escritora. Ahora debo hablar con entusiasmo de los muchos elementos originales del estilo: audacia, depuración, ingenuidad unidas a una sabiduría honda y nostálgica. Ex pede Herculem: que el lector aprecie el valor de lo siguiente: 
(La estrella dice al ciprés:) "-Tú no tienes belleza de corazón de nido, ni suavidad de alas frescas. Pero llega hasta mí el clamor de tus silencios, las imágenes de tus manos traspasadas de angustia, las crispaciones de tu frente en pensamiento. Por tu tremenda soledad de vivo entre los muertos te amo."

En estas voces ancladas, es decir, fijas, sometidas y humildes, hay un no sé qué de nobleza e ilusión que relaciona la obra con las Baladas del corazón cercano.

Consideremos Regreso. Esta breve colección se publicó en Mercedes del Uruguay, en el año 1934. En la página 5 leemos: "Adhesión al Congreso Eucarístico a celebrarse en Buenos Aires del 8 al 15 de Octubre de 1934." Excusado es decir qué honđa impresión dejó este Congreso en el espíritu rioplatense. Me imagino que Sarah Bollo, de educación y creencias católicas, se sentiría "despertada". Todas las fibras de su espíritu exquisitamente predispuestas para recibir y responder a' las dulces sugestiones del misticismo cristiano se estremecerían en los días de aquel año memorable. Fruto de místicos coloquios, de raptos de ferviente devoción, de momentos de contemplación amorosa del sublime drama de la vida, pasión y muerte de Jesucristo, es lo que debe descubrirse en Regreso. De las dieciséis poesías religiosas, cinco están acompañadas de versiones francesas escritas por Enrique Legrand. No nos equivoquemos: la misma poetisa "cerebral" que ha de escribir Baladas del corazón cercano escribe muchos de estos versos. Es innegable que hay mucho amor místico, sentimiento y emoción, pero no es puramente sentimental la mujer que escribe "Escuadra celeste". Aquí, contemplando sus obras, se adora la infinita majestad del Supremo Hacedor, y no se grita: “ Dios, sé propicio a mí, pecador!" Antes bien, se pregunta: “¿Cuál es el destino del hombre?", exactamente como aquel antiguo cantor que preguntó: “Qué es el hombre, para que tengas de él memoria?” Ella encuentra y anuncia, tabla de salvación en los versos que terminan esta bella poesía:

... Dios me ha mirado entre el lento pasar de la muchedumbre, me ha tocado en el pecho con la suave y ardiente mirada que constituye salvación y alegría.

Su curiosidad acerca de los astros pasa a ser la nostalgia de Dios, quien conduce en silencio esas huestes. De tal nostalgia y del conocimiento de que Dios la ha tocado, nace el Regreso. 
Interesantísimo es comparar las poesías de inspiración religiosa de los varios siglos y de las varias sectas y razas. Tal cual místico medieval nos impresiona con sus frases ritualistas; otro escribe versos de polémica; Francis Thompson canta del Galgo del cielo; muchos poetas norteamericanos contemporáneos están llenos de preocupaciones sociológicas. Pero esta uruguaya se califica en su poema "Bronce callado". He aquí versos que son todos adoración, rendimiento.

Jesús, bronce callado; campana loca era mi voz, sin bondo grito, sin canto ni sonrisa; yo creía que todo en la luz era santo, ahora veo que todo será santo si vienes.

Bajo túnica ardiente de asombro y armonía, pródigo hijo que llega temeroso y encuentra a su padre gozoso de la tarda venida, así llego a tu predio, me arrodillo y te hablo.

Jesús, bronce callado, con palabra ninguna se dirá lo que santo florece en la fragancia de tu lirio y tu sombra, tu frescor y tu amparo. Jesús, callado bronce, nada te digo y sabes.

Aún más devota se muestra en el apasionado "Ofertorio", en que hay reminiscencias del fervor de la Santa de Avila:

... en ti toda la dicha, todo el reposo, el cielo, la canción, la sonrisa, la frescura del río. Sobre tu pecho aquieta todo humano desvelo. Mi corazón te ama, tómalo, dueño mío.

Sea dicho de paso que "Ofertorio" es soneto que cumple rigorosamente con todos los requisitos prosódicos de esta forma poética. De los demás quince poemas de Regreso, pocos hay de que pueda decirse tanto. Tampoco ofrecen todos la misma fe ciega, amor callado. A veces la voz de Sarah se vuelve implorante:

Así combaten en mi pecho ansias secretas, sombras errantes, todos los ángeles de mi infortunio con los guerreros de mi dicha... ¡Oh Dios, oh Dios, dame la vaina de tu piedad, torna la espada en blando lirio. abre tus manos a mi llegada si es que me esperas en vida y muerte como sin tregua yo te espero!

("Apariciones sobre el estanque") 
Ritmos enérgicos o suaves; falta, por lo general, de rima; simbolismo que oscila entre los dos extremos -el religioso, que comprende la fe, y el cerebral, que apela a la inteligencia-: así es Regreso.

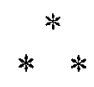

Baladas del corazón cercano (1935) pueden considerarse el fruto perfecto de esta poetisa, de quien escribió Alberto Zum Felde (Indice de la poesía uruguaya contemporánea): "Es la de imaginación más densa y lenguaje más rico... Esta poetisa ha podido conservar impoluta la gracia estética, bajo la acción opresiva de una cultura intelectual muy compleja". Dice el mismo crítico también esto, que si no se dijo precisamente de las Baladas, lo considero muy a propósito, ya que hablamos de ellas: "Su modalidad es absolutamente subjetiva, espiritualizada."

El examen de la "forma" de estas poesías nos revela lo siguiente: Las tres divisiones son:

\section{Baladas del corazón cercano \\ II. Gozosos destierros III. Canciones}

El estudio del vocabulario nos proporciona datos interesantes. A la poetisa parece que la fascinan las piedras preciosas: no todas, sino especialmente diamantes, jaspes, topacios, ópalos y esmeraldas. $A$ veces figuran las piedras en frases atrevidas:

Los ópalos me dan su brisa de seda serena.

$$
\text { (p. 24) }
$$

Los animales tienen carta regular de ciudadanía en el reino de su poesía: aparece el cisne (aquí de cuello incólume), aparecen leopardos, sierpes, leones, venados, luciérnagas, pájaros (pocos), gacelas (; ay! muchas) ...

Tocante a las flores, no cabe duda de que Sarah Bollo es aficionadísima a estos adornos de la poesía.

$$
\begin{aligned}
& \text {... Tú, en el alba y en la tarde, } \\
& \text { en el nardo y en la dalia, } \\
& \text { en las piedras y en los mares... } \\
& \text { dame por siempre la Iumbre, } \\
& \text { la rosa, el pan, la sonrisa. }
\end{aligned}
$$$$
\text { (p. 44) }
$$ 
Además de las cualidades de costumbre, da a las flores alguna que otra virtud especial. El lirio es "porfiado" (p. 40); los fresnos son "triunfantes" y el hibisco "colérico" (p. 45).

Es notable, también, cómo abunda la frase elíptica:

Te amo como te amo, matemáticas perfectas.

Acaso nací aquel día;

sangre con canto profundo;

navíos del pensamiento

batallas de gran tumulto.

$$
\text { (p. 9) }
$$

Esto llega a su máxima intensidad en la "Balada de los dos sacrificios", en cuyos veintidós versos no hay siquiera un solo verbo.

Se abusa del adverbio "tan":

Tu mano, tan de caricia...

$$
\text { (p. 20) }
$$

Debilidad, tan sentida.

Fortaleza tan ganada.

Pero hay que ver con cuánta maestría combina a veces el estilo abrupto, detallado sin pesadez y la frase atrevida, el hallazgo verbal:

... amo la gracia silvestre del viento que finge armonía;

la tierra me está mirando, pupilas de flor atenta;

el río toca mis manos, caricia fresca de espíritu;

cabelleras de los juncos rozan mis hombros, dormidos.

Por Dios, por Dios, Soledad, padezco con tanta dicha,

tengo en el pecho clavado, espada de lirio, el secreto;

si me lo dejan, perezco; si me lo arrancan, termino.

¿Multum in parvo!

Aunque en las Baladas hay gozo indecible, oyéndose la misma nota en las primeras canciones de "Gozosos destierros", hay que admitir que la pequeña nota amarga que apenas se oye en "Destrucción para la total llegada" llega a convertirse en conceptos claros y sonantes en las páginas que siguen. Asi es que a

matar el grito de la agonía 
le sucede

:Oh Dios, oh Dios, salva la mísera pasión, definitiva ciudadela!

$$
\text { (p. 100) }
$$

y

Lento círculo de agonía me aprieta la esperanza

(p. 109)

y estos versos finales de "Combate":

... recuerdo firme, qué espada:

esperanza, qué ceniza;

desesperanza, el abismo.

(p. 114)

La explicación de tal tristeza la buscaremos naturalmente en vano. El poeta está autorizado a guardar sus secretos. Canta, y cada uno puede interpretar la canción como se le antoje.

Leyendo las líneas

Vida, dame la delicia del encuentro con lo recién soñado; pero envíame luego en seguida la muerte, tu hábil detenedora, porque siento que voy a pedirte nuevos goces que tú ya no tienes.

(p. 124)

el lector queda impresionado de la nota excesivamente moderna, la de pedir nuevos goces. Esta demanda de algo superlativo, acaso forzosamente ha de acompañar muchas expresiones del Simbolismo.

Ya lo dije, Sarah es poetisa cerebral. "Continuo avión que crea su espacio", nos dice, "internos cielos alcé con impetu." (p. 100)

"Palabras por la mendiga" revelan st tendencia al raciocinio:

Niña mendiga que en la calle desierta bajo los soles dormidos del crepúsculo con lamentable ruego me detienes ¿sabes por qué prosigo sin mirarte?

Fuerte es este poema, pero no natural. No se puede negar que la inmediata y natural reacción ante la mendicidad, sobre todo la mendicidad juvenil, es la compasión. Luego, la claridad. La poetisa siente nacer aquélla, pero no practica ésta. Antes bien medita. De ahí la imponente gravedad de los versos, faltos un si es no es de naturalidad. 
Pero, aun así son tremendos. El aprecio que con justo motivo les tributamos no estorba el que prefiramos generalmente una lírica más ingenua, tratándose de la niñez. Ello es que esta autora no vive aislada de los "movimientos" y puntos de vista de su generación. Es "constructiva"; ¿ no nos lo dice ella misma en "Abandono sin humana presencia"?

Construyo siempre con tu recuerdo la más alegre salvación

y en "Ruego para un último día":

... Vida, tu arquitectura suplica necesaria corona.

(p. 124)

La nota espiritual que se oye en Regreso no falta en este libro. La evidencia es variable: ora superficial, ora intangible e interior. Superficialmente tenemos los versos de "Salvación de todos los caminos", y alguna súplica dirigida directamente al Ser Supremo. Pero no crea el lector que el crítico presente establezca la nota religiosa sobre la tenue base de tres repeticiones:

Dios que nos oye vió mi pobreza, seco sarmiento sin flor ni hoja;

Dios, el benigno, vió el largo manto de soledades que me cubría;

Dios, el benigno, tíó tu voz, cordel supremo de salvación...

(p. 93)

Tampoco convence su exquisita "Sinfonía de la llegada", en que saluda a su sobrinito recién nacido. Sin embargo, es todo lo tierna y todo lo religiosa que se quiera:

Con tus ojos, dormidos todavía a la luz,

Eres puente salvador entre arduas orillas,

Este mundo y la comarca de sombras.

Pero la espiritualidad de Sarah Bollo, y es una espiritualidad muy suya, se halla claramente revelada en el poema ya citado: "Palabras por la mendiga".

La poetisa se niega a darle la limosna que pide la niña, y sigue su camino:

Paso; no miro; hay rocío tras el párpado caído de los ojos;

mido y medito, ingeniero de internas construcciones dolorosas. 
¿Cuándo será que el desamor se temple

en la sangre ardiente de Cristo, espada de dulzura?

He aquí ternura insondable, amor a la niñez indefensa; pero nótese bien que es cariño que medita, y que consuela así a la pobre:

Necesario será conquistar el sagrado derecho de ser humano.

Tú pídelo con noble gesto, Antígona de maldito linaje; yo 10 pediré con grito y combate, con ruego y mandato.

Excusado es decir que para el lector de abolengo sajón, esta declaración de campaña por iniciarse en pro de la niñez mendicante anuncia una de las formas del "servicio social" más auténticas de aquella religión "pura y sin mácula" de que escribió el apóstol Santiago.

También en la categoría de referencias patentemente religiosas inclúyese su "Canción roja", poema de dos cuartetas y una quintilla, en el cual su inspiración rompe todas las cadenas, hasta poder decir:

Sol, diamante de arista arrecida, eres huella del sueño de Dios si en el día de mi nacimiento fugazmente pasé por su espíritu.

Sol, diamante de inmóviles albas, en tu acacia no vuelve el otoño; mi nostalgia ahora canta contigo. Dios nos ama, admirable alegría. Dios nos ama, belleza perfecta.

Pero, en general, debe decirse que estas Canciones (que constituyen la parte in del libro) parecen faltas de la inspiración más alta, pálidos reflejos de las emociones de los primeros grandes modernistas.

Sarah Bollo no es artista de vocación única. Con cierta apariencia de verdad se ha dicho que "a veces da la nota de Juana de Ibarbourou". Empero, ésta tocó por tiempo considerable la nota sensual, primitiva; Sarah casi nunca la toca. Es escritora intelectual. Si algunos de sus versos vibran apasionados, será porque quien los escribe saca de observación y memoria la materia de sus baladas. En lo que acertó mucho el crítico peruano L. A. Sánchez es en su frase: "la nota mixta y atemperada de Juana." Es cierto que Sarah es a veces alegre, triunfante por la fuerza del amor; pasa el instante de éxtasis, y sólo puede decir: "Yo sola, sin estar sola. Tu rostro bajo del 
párpado." (p. 30) ¡Autorretrato perfecto! :Imagen intachable de la reflexión, del ensimismamiento! Pero tal estado de deleite intelectual también pasa y ella se ve obligada a gemir:

Cuchilla de plata, la luna;

cuchilla de plata en el pecho.

Debajo el dócil venado,

el corazón en tormento.

Hogueras de sombra, los pinos:

hogueras de sombra en el viento.

Debajo en la llama mordido,

el corazón, frágil leño.

Por cierto, la crítica que escribió La poesía de Juana de Ibarbourou (1935), esa misma se sentiría estrechamente unida a doña Juana, al menos cuando canta de su "universo transfigurado". Pero Sarah Bollo es mujer que no sólo canta; también sabe razonar y suele explayar brillantemente sus razones en conferencias de recia contextura y de estilo refinadísimo. Que su poesía tenga alguna vez referencia a los sentidos, pase; que su metáfora es a menudo audaz, concedámoslo; que conserva la tradición de los simbolistas, lo prueban muchas de las citas de este estudio. ( $Y$ si no, léase su magnífico "Mares del sur", que nos dejó casi hostigados con la obsesión de que aquí hay ecos de Herrera y Reissig.) Pero en su voz hay algo más que reminiscencias de la exquisitez del poeta de La torre de los panoramas. Hay una inteligencia que se confirma con cada paso de la observación creciente. (Y esto vale decir que Sarah cada vez más hará poesía filosofando.) Así se explica el fenómeno quizá más característico de las Baladas del corazón cercano: en todas sus páginas se siente que la poetisa ha reservado algo, no por cierto lo menos importante y vital de su "yo". Cuando, tras más vivir y observar, se presente el momento propicio, nos regalará con otras producciones de su "cerebración" rítmica, y serán al mismo tiempo otros tantos arranques de emoción muy honda.

HenRY A. Holmes, College of the City of New York. 